\title{
Effects of Combination of Inorganic and Organic Fertilizers Application on Morphology and Physiology of Immature Oil Palm
}

\author{
DOI: 10.18196/pt.2019.096.73-81
}

\author{
Zahrul Fuady*, Halus Satriawan, Agusni \\ Department of Agrotechnology, Faculty of Agriculture, Universitas Almuslim, \\ Jl. Almuslim, Matangglumpangdua, Bireuen, Aceh 24261, Indonesia \\ *Corresponding author, email: zahrulfuady17@yahoo.com
}

\begin{abstract}
Oil palm requires nutrients both macro and micro nutrients for its growth and development processes. This study aimed to study the morphological and physiological responses of immature oil palm plantations at 1 year of planting to the provision of organic fertilizer and micro fertilizers as a complement to inorganic fertilizers. The research was arranged in a Randomized Completely Block Design (RCBD). The treatment applied consisted of 7 treatments, namely one control treatment (basic fertilizer) and six treatments from a combination of type and dose of fertilizer, consisting of single fertilizer, compound fertilizer, organic fertilizer and micro fertilizer. Based on the results, single and compound fertilizers accompanied by micro fertilizers (M1a, M1b) had a significant effect on plant height showing 13.78\%, 27.55\%, 25.11\%, and 54.18\% higher than others andon length and width of the 9th midrib reaching 7.47\%, 22.40\% and 51.04\% better than others. The best response of growth of stem circumference at 6 MAT was observed in P01 reaching 112.43\%, better than M1a (111.96\%)and M1b (109.20), while the lowest was observed in P0O (97.84\%). Meanwhile, chlorophyll and stomata were implied by a package of compound fertilizer and single fertilizer. The highest leaf chlorophyll content was in the MOa fertilizer treatment, while the highest stomata level was in the M1a treatment..
\end{abstract}

Keywords: Fertilization packages, Oil palm, Immature plants, Vegetative growth, Physiological growth

\begin{abstract}
ABSTRAK
Kelapa sawit membutuhkan nutrisi untuk proses pertumbuhan dan perkembangannya, baik nutrisi makro maupun mikro. Penelitian ini bertujuan untuk mempelajari respon morfologis dan fisiologis dari perkebunan kelapa sawit belum menghasilkan pada 1 tahun tanam karena pemberian pupuk organik dan pupuk mikro sebagai pelengkap pupuk anorganik. Percobaan menggunakan Rancangan Acak Kelompok Lengkap (RAK). Perlakuan yang diterapkan terdiri dari 7 perlakuan, yaitu satu perlakuan kontrol (pupuk dasar) dan enam perlakuan dari kombinasi jenis dan dosis pupuk, terdiri atas pupuk tunggal, pupuk majemuk, pupuk organik, dan pupuk mikro. Berdasarkan hasil yang diperoleh, pupuk tunggal dan pupuk majemuk yang disertai dengan pupuk mikro (Mla, M1b) memiliki pengaruh signifikan terhadap tinggi tanaman, dengan persentase 13,78\%,27,55\%,25,1 1\%, dan 54,18\% lebih tinggi dibandingkan perlakuan lainna; Parameter panjang dan lebar daun pelepah ke-9 lebih baik 7,47\%,22,40\% dan 51,04\% dibandingkan perlakuan lainnya. Pertumbuhan lingkar batang pada 6 bulan setelah pelakuan terbaik pada P01 setara dengan 1 12,43\%, lebih baik dibandingkan M1 a (1 1 1,96\%), dan M1 b (109,20), terendah pada P00 (97,84). Sementara klorofil dan stomata diimp likasikan oleh paket pupuk majemuk dan pupuk tunggal. Kandungan klorofil daun tertinggi ada pada perlakuan pupuk MOa, sedangkan kadar stomata tertinggi ada pada perlakuan Mla.

Kata Kunci: Paket pemupukan, Kelapa sawit, Tanaman belum menghasilkan (TBM), Pertumbuhan vegetatif, Pertumbuhan fisiologi
\end{abstract}

\section{INTRODUCTION}

One factor that plays an important role in crop productivity is fertilization (Adam et al. 2005, 2011; Sun et al., 2011; Wigena et al. 2009; Zuraidah et al. 2012) especially in the phase of immature plants (TBM). Therefore, given the high cost, fertilization is an aspect that must be considered in oil palm cultivation. Fertilization costs range from $40-60 \%$ of plant maintenance costs or about $30 \%$ of the total production costs (Goh and Hardter, 2003). As a provider of plant nutrition, nutrient availability which is a limiting factor of plant growth and production is highly dependent on location, mostly due to soil characteristics (Woittiez et al., 2017).

Like other plants, oil palm also requires nutrients both macro and micro nutrients for its growth and development processes. Macro nutrients play a major role in the constituent of cell protoplasm so that it is needed in large quantities. Macro nutrients include $\mathrm{C}, \mathrm{H}, \mathrm{O}, \mathrm{N}, \mathrm{P}, \mathrm{K} \mathrm{Ca}, \mathrm{Mg}$ and $\mathrm{S}$. Meanwhile, micro nutrients are needed in very 
small quantities. If there is an excessive amount it can be toxic to plants. Micro nutrients include Fe, $\mathrm{Mn}, \mathrm{B}, \mathrm{Mo}, \mathrm{Cu}, \mathrm{Zn}, \mathrm{Cl}$ and $\mathrm{Co}$ (Hardjowigeno, 2010). Moreover, oil palm plants are known as plants that require high amounts of fertilizer, considering that 1 ton of FFB produced is equivalent to $6.3 \mathrm{~kg}$ of urea, $2.1 \mathrm{~kg}$ of TSP, $7.3 \mathrm{~kg}$ of MOP, and $4.9 \mathrm{~kg}$ of Kiserit (Poeloengan et al., 2001). According to Tarmizi (2000), oil palm cultivated in tropical regions such as in Malaysia requires 0.5-1.1 $\mathrm{kg} \mathrm{N}, 1.1 \mathrm{~kg} \mathrm{P}_{2} \mathrm{O}_{5}$, and 0.5-2.2 $\mathrm{kg} \mathrm{K} \mathrm{O}_{2}$ per year.

Fertilization with optimum doses aims to provide sufficient and effective nutrients to encourage healthy vegetative growth of plants and maximize the potential for fresh fruit bunches production (Tarmizi and Tayeb, 2006; Prasetyo and Suriadikarta, 2006), to increase efficiency (Poeloengan et al, 2007 ) and to replace nutrients that are lost from the soil through washing, erosion and extraction by the plants themselves (Law et al., 2012). Nutrients given through fertilization must be based on the principle of balanced fertilization, which is to provide nutrients according to the needs of plants. Giving fertilizer with a lower dosage than the plant needs will not give optimal influence for the growth and production of plants both in quality and quantity, while fertilizer application exceeding the needs of plants will reduce the quality of the environment and decrease the growth and production of plants (Safuan et al., 2013).

In addition to inorganic fertilizers, fertilizer can also be in the form of organic fertilizers, such as manure, green manure, and compost. Providing organic fertilizer can increase nutrient content in the soil, although the nutrient content in organic fertilizer is relatively low (Uwumarongie et al., 2012). The results of the study by Kanny et al. (2015) showed that oil palm given with certain level of $\mathrm{P}$ nutrient had not yielded at the age of 2 years, while the provision of organic fertilizer with a dose of $90 \mathrm{~kg} /$ plant / year could give the best effect. In addition, Siallagan et al. (2014) showed that a combination of inorganic and organic fertilizers resulted in a good plant height and stem circumference in oil palm plants that had not yielded at the age of 1 year of planting. The provision of inorganic fertilizers and organic fertilizers can also improve physiological growth in oil palm plants.

Besides being beneficial to plant growth, organic fertilizers are also known for soil nutrient flux compared to organic fertilizers, enriching soil fertility in a longer period of time (Khatun et al., 2017). In addition, providing organic fertilizer can increase the water holding capacity and the cation exchange capacity of the soil so that if inorganic fertilizer is added, washing by rainwater and erosion can be inhibited (Sukmawan, et al., 2015).

This study aimed to study the morphological and physiological responses of immature oil palm plantations at 1 year of planting to the provision of organic fertilizer and micro fertilizers as a complement to inorganic fertilizers.

\section{MATERIALS AND METHODS}

The experiment was carried out in Bukit Sudan Village, sub-District of Peusangan Siblah Krueng, Bireuen District, Aceh, located at an altitude of 120 $\mathrm{m}$ above sea level. This research was carried out for 9 months starting from March - November 2018. The data presented in this article are research data for 6 months after application (April-September). The field experiment was conducted in community oil palm plantation in Peusangan Siblah Krueng Subdistrict, Bireuen Regency of Aceh Province (5'4'30" N and 96 45'18” E with 116 m elevation), which previously had been determined slightly sloping or bumpy (8-15\%), with mild - moderate soil depth $(85-125 \mathrm{~cm})$. The soil of the experimental area is classified as Typic Paleudults (USDA, 2010). The parent material is dominated by andesite rocks. 
The texture of the soil in the study area is classified as sandy clay in the topsoil (0-0.15 m depth), having a deep argillic horizon with clay content between 19 and 37\%. Rainfall events generated with total rainfall recorded amount is $1,895 \mathrm{~mm}$.

The ingredients used were oil palm varieties DP-9, cow manure, urea, phosphate, NPK, terusi $\left(\mathrm{CuSO}_{4 \cdot 5} \mathrm{H}_{2} \mathrm{O}\right)$, rock phosphate, and Borat fertilizer. The tools used were analytic scales, meters, chlorophyll meters, microscopes, ovens, and preparate / glass objects.

The research was arranged in a Randomized Completely Block Design (RCBD) design in which grouping was done based on land slope. The treatment applied consisted of 7 treatments, namely one control treatment (basic fertilizer) and six treatments from a combination of type and dose of fertilizer, consisting of single fertilizer, compound fertilizer, organic fertilizer and micro fertilizer (Table 1). Each treatment was replicated three times and each experimental unit consisted of five oil palm plants so that the total experimental unit was 63 plants.

Fertilization

All oil palm plants have been previously fertilized with $60 \mathrm{~kg} /$ hole organic manure, $500 \mathrm{gr} /$ planting hole cow manure and dolomite as much as 500 grams / planting hole (basic fertilizer). Fertilizer application according to treatment was carried out three times, i.e. every four months with a minimum rainfall of $60 \mathrm{~mm} /$ month (in March and July).

Application of urea, SP-36, $\mathrm{KCl}$, compound NPK, organic fertilizer and micro fertilizer was carried out in the morning by sprinkling fertilizer on the palm oil larikan and disks (Soon and Hoong, 2002) except the application of borate fertilizer which was stocked on the leaf midribs. (Goh and Hardter, 2003).

\section{Morphological Observations on Plants}

Morphological observations on plants were carried out on each experimental unit every 3 months. The height of the plant was measured from the base of the stem marked up to the youngest leaf opening perfectly enforced using a modified fabric meter (Siallagan, et al., 2014)

Number of leaf midribs. The number of leaf midribs counted were leaf midribs that had opened (Legros et al., 2009). The stem circumference is a collection of leaf midribs that are still wrapped in fibers. Measurements were made using a fabric meter at $5 \mathrm{~cm}$ from the ground level (Legros et al., 2009). The length of the 9 th from leaf midrib were made with a fabric meter, starting from the base of the midrib to the tip of the midrib. The measurement of leaf size was carried out on the 9th leaf midrib, by measuring several strands of the length and width of the leaflets and they were calculated by the formula by Sudrajat et al. (2015):

Table 1. Treatment of various levels of immature oil palm fertilization

\begin{tabular}{|c|c|}
\hline Fertilizer Level & Combination and Type of Fertilizer (plant / year) \\
\hline POO & $600 \mathrm{~g}$ urea $+750 \mathrm{~g} \mathrm{SP}-36+700 \mathrm{~g} \mathrm{KCl}+25 \mathrm{~g}$ borate $+25 \mathrm{~g} \mathrm{CuSO}_{4} \cdot 5 \mathrm{H}_{2} \mathrm{O}$ \\
\hline P01 & $1300 \mathrm{~g} \mathrm{NPK}+25 \mathrm{~g}$ borate $+25 \mathrm{~g}$ CuSO $4.5 \mathrm{H} 2 \mathrm{O}+30 \mathrm{~kg}$ cow manure fertilizer \\
\hline PO2 & $\begin{array}{l}600 \mathrm{~g} \text { urea }+750 \mathrm{~g} \mathrm{SP}-36+700 \mathrm{~g} \mathrm{KCl}+25 \mathrm{~g} \text { borate }+25 \mathrm{~g} \mathrm{CuSO}_{4} \cdot 5 \mathrm{H}_{2} \mathrm{O}+30 \mathrm{~kg} \\
\text { cow manure fertilizer }\end{array}$ \\
\hline Single fertilizer with micro fertilizer (M1a) & $600 \mathrm{~g}$ urea $+750 \mathrm{~g} \mathrm{SP}-36+700 \mathrm{~g} \mathrm{KCl}+25 \mathrm{gr}$ borate $+25 \mathrm{~g} \mathrm{CuSO}_{4} \cdot 5 \mathrm{H}_{2} \mathrm{O}$ \\
\hline Compound fertilizer with micro fertilizer (M1b) & $1300 \mathrm{~g} \mathrm{NPK}+25 \mathrm{~g}$ borate $+25 \mathrm{~g} \mathrm{CuSO}_{4} \cdot 5 \mathrm{H}_{2} \mathrm{O}$ \\
\hline Single fertilizer without micro fertilizer (M0a) & $600 \mathrm{~g}$ urea $+750 \mathrm{~g} \mathrm{SP}-36+700 \mathrm{~g} \mathrm{KCl}$ \\
\hline Compound fertilizer without micro fertilizer (M0b) & $1300 \mathrm{~g} \mathrm{NPK}$ \\
\hline
\end{tabular}




$$
\text { Leafsize }=\frac{\sum_{1}^{6} p \times l}{6} \times 2 n \times k
$$

Description:

$\mathrm{p}=$ the length of the leaflets $(\mathrm{cm})$

1 = width of leaflets

$\mathrm{n}=$ number of left or right leaflets

$\mathrm{k}=$ constant $(0.57$ for TBM $)$

\section{Stomata density.}

Observation of leaf stomata density was carried out at 8 months after treatment. Observation of stomatal samples was carried out by applying transparent nail polish on the bottom surface of the 9th leaf midrib, about $2 \mathrm{~cm} \mathrm{x} 2 \mathrm{~cm}$ in the morning and it was allowed to dry. Transparent tape was then taped on the surface of the leaf that has been smeared with nail polish, so that the nail polish sticked perfectly. After that the tape was released and affixed to the object glass. Stomata were observed under an electron microscope at a magnification level of 40 . The stomata density was calculated by the following formula (Rahhutami, 2015):

\section{Stomata density $=\frac{\text { Number ofStomata }}{\text { broad field } \boldsymbol{6} \text { view }}$}

The area of view was calculated by the formula: $\mathrm{A}=\pi \mathrm{r}^{2}$

$=3.14 \times(0.25)^{2}$

$=0.19625 \mathrm{~mm}^{2}$

\section{Chlorophyll content of leaves.}

Chlorophyll content was measured by observing the greenness level of leaves with chloropyll meters every 4 months for 12 months on the 9th midrib leaf. This tool digitally measures the greenness and the relative amount of chlorophyll molecules contained in the leaves in one value which is based on the amount of light transmitted by the leaves. Leaf samples were placed at the point of the reader, then the reader button was pressed. Measurements were made at three points (base, middle and end) which were $\pm 5 \mathrm{~cm}$ from the edge of the leaflet. The real value of chlorophyll content was calculated using the formula by Farhana et al. (2007): $Y=0.0007 x$ -0.0059 , where: $\mathrm{Y}=$ chlorophyll content and $\mathrm{X}=$ measurement result value.

\section{RESULTS AND DISCUSSION}

Plant height

The results showed that the treatment of organic fertilizers and micro fertilizers significantly affected the height of oil palm plants at 1, 3 and 6 months after treatment (MAT) (Table 2).

The treatment of compound fertilizers with micro fertilizers (M1b) resulted in the highest growth of plant height at 1 MAT, 3 MAT and 6 MAT compared to other treatments. However, in terms of increasing the growth rate at 1, 3 and 6 MAT, the best effect was obtained in the M1a treatment, namely: $13.78 \%$, 27.55\%, 25.11\%, and 54.18\%.

In Table 2, it can be seen that single fertilizer supplementation with addition of $\mathrm{Cu}$ and borate micro fertilizers can increase the best plant height. Compared to other treatments, during the initial growth stage, plants fertilized with a single fertilizer with the addition of micro fertilizer were more

Table 2. Effect of doses of organic fertilizer and micro fertilizer on plant height

\begin{tabular}{ccccc}
\hline \multirow{2}{*}{ Fertilizing Level } & \multicolumn{4}{c}{ Plant Height (cm) } \\
\cline { 2 - 5 } & Initial & 1 MAT & 3 MAT & 6 MAT \\
\hline PO0 & 117.99 & $131.47 \mathrm{c}$ & $144.95 \mathrm{~b}$ & $179.15 \mathrm{~b}$ \\
P01 & 116.49 & $128.06 \mathrm{ab}$ & $147.63 \mathrm{~d}$ & $178.63 \mathrm{~b}$ \\
P02 & 118.73 & $132.13 \mathrm{c}$ & $146.53 \mathrm{~cd}$ & $177.93 \mathrm{~b}$ \\
M1a & 114.04 & $129.75 \mathrm{~b}$ & $145.46 \mathrm{bc}$ & $179.46 \mathrm{~b}$ \\
M1b & 118.94 & $134.90 \mathrm{~d}$ & $149.86 \mathrm{e}$ & $182.86 \mathrm{c}$ \\
M0a & 118.00 & $131.48 \mathrm{c}$ & $144.96 \mathrm{~b}$ & $179.16 \mathrm{c}$ \\
M0b & 112.95 & $126.76 \mathrm{a}$ & $140.57 \mathrm{a}$ & $174.14 \mathrm{a}$ \\
\hline LSD & & 1.22 & 1.22 & 1.22 \\
\hline
\end{tabular}

Note: Values followed by different letters in the same column are significantly different according to LSD test at $5 \%$ level. 
responsive than those fertilized with other types of fertilizers (compound fertilizer and addition of manure). This can be seen in observations at 1 and 3 MAT, while at 6 MAT, 6 of 7 treatments produced plant growth $>50 \%$. The results of this study is not in accordance with the findings of Syahputra and Wardati (2015) and Siallagan and Wardati (2015) reporting thatfertilization of compound fertilizers and $\mathrm{Cu}$ did not have a significant effect on plant growth in peatland.

In this case, nitrogen plays a role in the photosynthesis process which produces assimilates needed by plants during the morphological growth phase (Suharno et al., 2007). This result is also in line with the phenomenon of the results of Luz et al. (2006) who reported that nitrogen fertilizer increased and accelerated the growth of "lady palm" plant seeds (Rhapis excels). Goh and Hardter (2003) showed that nitrogen fertilization was the main driving force for rapid vegetative growth of oil palm. Likewise, Kasno et al. (2010) showed that giving phosphorus fertilizer significantly increased the height of oil palm seedlings. The $\mathrm{Cu}$ element contributes to chlorophyll formation and also plays a role in symbiotic $\mathrm{N}$ fixation and lignin preparation.

\section{Stem circumference}

The results of fertilization treatment analysis showed that there was a significant effect on the circumference of the oil palm stems in each observation period (Table 3). In each observation period, the largest stem circumference growth was found in different treatments. The best response in stem circumference growth at 1 MAT was found in $\mathrm{MOa}$ and $\mathrm{POO}$ treatment, at 3 MAT was in $\mathrm{MOa}$ treatment and at 6 MAT was in PO1. The growth of stem circumference for the treatment of PO1 at 6 MAT was equivalent to $112.43 \%$ since the beginning of planting, the highest compared to other
Table 3. Effect of doses of organic fertilizer and micro fertilizer on stem circumference

\begin{tabular}{ccccc}
\hline \multirow{2}{*}{ Fertilizing Level } & \multicolumn{4}{c}{ Stem Circumference $(\mathrm{cm})$} \\
\cline { 2 - 5 } & Initial & 1 MAT & 3 MAT & 6 MAT \\
\hline P00 & 19.8 & $23.4 \mathrm{c}$ & $33.5 \mathrm{~b}$ & $39.1 \mathrm{~b}$ \\
P01 & 19.0 & $22.6 \mathrm{a}$ & $34.3 \mathrm{e}$ & $40.4 \mathrm{~d}$ \\
P02 & 19.8 & $23.0 \mathrm{~b}$ & $34.0 \mathrm{~d}$ & $40.2 \mathrm{c}$ \\
M1a & 18.9 & $22.6 \mathrm{a}$ & $33.8 \mathrm{c}$ & $40.1 \mathrm{c}$ \\
M1b & 18.8 & $22.6 \mathrm{a}$ & $34.0 \mathrm{~d}$ & $39.3 \mathrm{~b}$ \\
M0a & 19.7 & $23.4 \mathrm{c}$ & $34.5 f$ & $40.1 \mathrm{c}$ \\
M0b & 19.4 & $22.7 \mathrm{a}$ & $32.6 \mathrm{a}$ & $38.6 \mathrm{a}$ \\
\hline LSD & & 0.19 & 0.19 & 0.19 \\
\hline
\end{tabular}

Note: Values followed by different letters in the same column are significantly different according to LSD test at $5 \%$ level.

treatments, i.e. $111.96 \%$ (M1a), 109.20 (M1b), and the lowest in POO (97.84\%).

In the stem circumference growth parameter, PO1 treatment $(1300 \mathrm{~g} \mathrm{NPK}+25 \mathrm{~g}$ borate $+25 \mathrm{~g}$ $\mathrm{CuSO}_{4} \cdot 5 \mathrm{H}_{2} \mathrm{O}+30 \mathrm{~kg}$ cow manure) most significantly stimulated the growth of stem circumference. The use of compound fertilizers combined with manure and micro elements that are slow in nature was able to influence the growth at 3 and 6 MAT. It is suspected that compound fertilizer and $\mathrm{Cu}$ after 3 months of application can be utilized by oil palm plants. This result is consistent with the research of Uwumarongie-Ilori et al. (2012) and Siallagan et al. (2014) showing that application of organic fertilizer can increase stem circumference as a result of improvement of soil physical and chemical properties. Organic fertilizer applications are beneficial for plants for the long term because the nutrients contained in them are released slowly (Ermadani and Muzar, 2011). In addition, organic fertilizer can also improve rhizosphere so that it can maintain the nutrient cycle andimprove exudation by plant roots which can increase the degradation of soil organic matter and $\mathrm{N}$ mineralization (Suprayitno et al., 2017). Tiemann et al. (2018) also state that the stem is an area of nutrient accumulation during plant growth, which is around $35-40 \%$. The avail- 
ability of nutrients in sufficient quantities causes the metabolic activity of the plant to increase so that the enlargement of the stem occurs.

\section{Number of Leaf midribs}

Fertilization treatment resulted in significant effect on the amount of oil palm leaf midrib at each observation period (Table 4). PO1 treatment is known to produce the highest number of leaf midribs at three observation periods $(1,3$ and 6 MAT). However, the highest e number of leaf midribs obtained in M0a treatment was 17\%, 51\% and $85 \%$ at three observation periods.

Table 4. Effect of doses of organic fertilizer and micro fertilizer on the number of leaf midribs

\begin{tabular}{ccccc}
\hline \multirow{2}{*}{ Fertilizing Level } & \multicolumn{4}{c}{ Number of Leaf Midribs (sheet) } \\
\cline { 2 - 5 } & Initial & 1 MAT & 3 MAT & 6 MAT \\
\hline P00 & 14.30 & $16.55 \mathrm{~d}$ & $19.95 \mathrm{a}$ & $23.35 \mathrm{a}$ \\
P01 & 14.33 & $16.48 \mathrm{~cd}$ & $20.78 \mathrm{e}$ & $25.08 \mathrm{e}$ \\
P02 & 14.13 & $16.31 \mathrm{c}$ & $20.66 \mathrm{de}$ & $25.01 \mathrm{e}$ \\
M1a & 13.80 & $15.98 \mathrm{~b}$ & $20.28 \mathrm{bc}$ & $24.58 \mathrm{c}$ \\
M1b & 13.73 & $15.96 \mathrm{~b}$ & $20.46 \mathrm{~cd}$ & $24.96 \mathrm{de}$ \\
M0a & 13.23 & $15.48 \mathrm{a}$ & $19.98 \mathrm{a}$ & $24.48 \mathrm{c}$ \\
M0b & 13.43 & $15.61 \mathrm{a}$ & $19.91 \mathrm{a}$ & $24.21 \mathrm{~b}$ \\
\hline LSD & \multicolumn{5}{c}{0.21} & 0.21 & 0.21 \\
\hline
\end{tabular}

Note: Values followed by different letters in the same column are significantly different according to LSD test at $5 \%$ level.

The results showed that midrib production ranged from 15-24 strands at 6 months after treatment with an average of $2-4$ strands per month (Table 4). This amount is higher than the midrib production under normal land conditions, which is about 2 strands per month (Corley and Tinker, 2008). Midrib production in the first year is low and will then reach a maximum in the second year (Adam et al., 2011). Midrib production seems also related to climate factors, such as rainfall. Midrib production in a month is affected by the amount of rainfall one or two months before. In this study, rainfall in July and August was higher than in the previous month.

\section{The Length and Area of the 9th Leaf Midrib}

Fertilization treatment has a significant effect on the length of the 9th leaf midrib of oil palm at each observation period (Table 5). M1a treatment is known to produce the best leaf midrib growth at three observation periods (1, 3 and 6 MAT). Likewise, if the leaf midrib growth is converted as a percentage of growth rate, it is best obtained in treatment M1a of $7.47 \%, 22.40 \%$ and $51.04 \%$ at three observation periods. Meanwhile, the lowest growth rate was in the treatment of $\mathrm{PO} 2(3.09 \%$, $9.28 \%$ and $18.07 \%)$.

Fertilization treatment has a significant effect on the length of the 9th leaf midrib of oil palm at each observation period (Table 5). The treatment of $\mathrm{M} 1 \mathrm{~b}$ is known to produce the best leaf midrib area at two observation periods (1 and 3 MAT), while in 6 MAT the widest leaf midrib area was observed in PO2. Likewise, if the growth of leaf midrib area is converted as a percentage of growth rate, the best was obtained in M1b treatment of 39\%, 78\% and $103 \%$ at three observation periods.

This result is consistent with that stated by Corley and Tinker (2008) that leaf area and length of midrib were affected by fertilization, but not too sensitive to other factors. The canopy size which is related to leaf area, midrib length, and number of leaflets has a changing growth pattern. Change in

Table 5. Effect of doses of organic fertilizer and micro fertilizer on the length of the $9^{\text {th }}$ leaf midrib

\begin{tabular}{ccccc}
\hline \multirow{2}{*}{ Fertilizing Level } & \multicolumn{4}{c}{ The Length of the $9^{\text {th }}$ Leaf Midrib $(\mathrm{cm})$} \\
\cline { 2 - 5 } & Initial & 1 MAT & 3 MAT & 6 MAT \\
\hline PO0 & 91.26 & $96.06 b$ & $105.66 \mathrm{c}$ & $134.20 \mathrm{e}$ \\
P01 & 93.27 & $96.90 \mathrm{c}$ & $104.15 \mathrm{~b}$ & $128.67 \mathrm{~b}$ \\
P02 & 92.43 & $95.29 \mathrm{a}$ & $101.01 \mathrm{a}$ & $109.14 \mathrm{a}$ \\
M1a & 90.65 & $97.41 \mathrm{~d}$ & $110.95 \mathrm{e}$ & $139.25 \mathrm{~g}$ \\
M1b & 90.82 & $97.03 \mathrm{c}$ & $109.45 \mathrm{~d}$ & $137.17 \mathrm{f}$ \\
M0a & 91.53 & $96.34 \mathrm{~b}$ & $105.96 \mathrm{c}$ & $129.80 \mathrm{c}$ \\
M0b & 91.07 & $95.97 \mathrm{~b}$ & $105.77 \mathrm{c}$ & $131.78 \mathrm{~d}$ \\
\hline LSD & & 0.49 & 0.49 & 0.49 \\
\hline
\end{tabular}

Note: Values followed by different letters in the same column are significantly different according to LSD test at $5 \%$ level. 
Table 6. Effect of doses of organic fertilizer and micro fertilizer on the area of the $9^{\text {th }}$ leaf midrib

\begin{tabular}{ccccc}
\hline \multirow{2}{*}{ Fertilizing Level } & \multicolumn{4}{c}{$9^{\text {th }}$ Leaf Midrib Area $\left(\mathrm{cm}^{2}\right)$} \\
\cline { 2 - 5 } & Initial & 1 MAT & 3 MAT & 6 MAT \\
\hline P00 & 0.57 & $0.67 b$ & $0.87 b$ & $0.95 b$ \\
P01 & 0.56 & $0.65 b$ & $0.83 b$ & $0.95 b$ \\
P02 & 0.57 & $0.67 b$ & $0.87 b$ & $1.13 \mathrm{~d}$ \\
M1a & 0.54 & $0.65 b$ & $0.85 b$ & $1.00 \mathrm{bc}$ \\
M1b & 0.50 & $0.70 b c$ & $0.89 \mathrm{c}$ & $1.02 \mathrm{c}$ \\
M0a & 0.57 & $0.68 b$ & $0.88 \mathrm{bc}$ & $1.04 \mathrm{c}$ \\
M0b & 0.43 & $0.54 \mathrm{a}$ & $0.75 \mathrm{a}$ & $0.88 \mathrm{a}$ \\
\hline LSD & & 0.05 & 0.05 & 0.05 \\
\hline
\end{tabular}

Note: Values followed by different letters in the same column are significantly different according to LSD test at 5\% level.

Table 7. Effect of doses of organic fertilizer and micro fertilizer on leaf chlorophyll content and stomatal density

\begin{tabular}{cccc}
\hline \multirow{2}{*}{ Fertilizing Level } & \multicolumn{2}{c}{ Leaf Chlorophyll } & Stomata density \\
\cline { 2 - 4 } & 4 MAT & 8 MAT & 8 MAT \\
\hline P00 & $0.0450 \mathrm{~d}$ & $0.0433 \mathrm{~b}$ & $206.33 \mathrm{~b}$ \\
P01 & $0.0427 \mathrm{a}$ & $0.0417 \mathrm{a}$ & $205.22 \mathrm{a}$ \\
P02 & $0.0443 \mathrm{c}$ & $0.0440 \mathrm{c}$ & $208.07 \mathrm{c}$ \\
M1a & $0.0477 \mathrm{c}$ & $0.0430 \mathrm{~b}$ & $208.30 \mathrm{c}$ \\
M1b & $0.0437 \mathrm{ab}$ & $0.0427 \mathrm{ab}$ & $208.20 \mathrm{c}$ \\
M0a & $0.0447 \mathrm{c}$ & $0.0447 \mathrm{c}$ & $206.63 \mathrm{~b}$ \\
M0b & $0.0460 \mathrm{~d}$ & $0.0410 \mathrm{a}$ & $206.60 \mathrm{~b}$ \\
\hline LSD & 0.001 & 0.001 & 0.48 \\
\hline
\end{tabular}

Note: Values followed by different letters in the same column are significantly different according to LSD test at 5\% level.

canopy size is an adaptation mechanism for regulating transpiration rate as responsive to changes in plant water balance (Yahya and Manurung, 2002).

The function of element $\mathrm{N}$ is for overall plant growth, namely for protein formation, chlorophyll synthesis, and metabolic processes (Rachman et al., 2008). P element acts as an ATP molecule forming element which is an energy-rich molecule that is needed in metabolic processes such as protein synthesis, so that $\mathrm{P}$ nutrient deficiency can cause stunted growth (Goh and Hardter, 2003). K element acts as an enzyme activator and maintains osmotic potential and water uptake, as well as translocation of photosynthetic results out of the leaves to the sink (Pettigrew, 2008).

\section{Stomata Density and Leaf Chlorophyll Content}

In general, fertilization treatment has significant effect on leaf chlorophyll content at 4 and 8 MAT, and stomata density at 8 MAT (Table 7). The highest leaf chlorophyll content was in the MOa fertilizer treatment, while the highest stomata density was in the M1a treatment.

Stomata density is influenced by temperature, light intensity and plant adaptation to the environment. Taiz and Zeiger (2006) stated that high density and number of stomata are strongly influenced by plant adaptation to their environment. The stomata density in this study was between 205-208 $\mathrm{mm}^{-2}$. Stomatadensity of oil palm leaves depends on the characteristics of an area. The stomata density of oil palm leaves in Nigeria and Malaysia is 146 $\mathrm{mm}^{-2}$ and $175 \mathrm{~mm}^{-2}$, respectively. The oil palm leaf stomata are classified as semi-xeromorphic which has a structure to adapt to long dry periods (Corley and Tinker, 2008).

Even so, leaf chlorophyll content tended to decrease during the 8th month compared to the 4 th month after planting. The provision of organic fertilizer and compound NPK up to the highest dose has not been able to increase the chlorophyll content of immature oil palm until the end of the (Table 7). This is predicted because the doses of fertilizer are is still not sufficient or the plant takes longer time to be able to respond to fertilizer. Associated with the function of nutrients to the formation of leaf chlorophyll, Simbolon and Zuhri (2017) explained that nitrogen is beneficial for the formation of chlorophyll which is very important for photosynthesis so that it can increase plant growth. Photosynthesis will work well with the availability of $\mathrm{K}$ in sufficient quantities. Potassium 
can function to form and transport carbohydrates, increasing the growth of meristem tissue.

\section{CONCLUSION}

Single and compound fertilizers accompanied by micro fertilizers (M1a, M1b) have significant effect on plant height, length and width of the 9th midrib leaf. Variables of stem circumference and number of midribs were adhered to by a package of compound fertilizer + micro + manure, while chlorophyll and stomata were implied by a package of compound fertilizer and single fertilizer. However, in terms of increasing the growth rate in plant height at 1, 3 and 6 MAT, the best effect was observed in M1a treatment, namely: $13.78 \%, 27.55 \%, 25.11 \%$, and $54.18 \%$. The best stem circumference growth at 1 MAT was found in $\mathrm{MOa}$ and $\mathrm{POO}$ treatment, at $3 \mathrm{MAT}$ was in $\mathrm{MOa}$ treatment and at 6 MAT was in PO1. The growth of stem circumference for the treatment of PO1 at 6 MAT was equivalent to $112.43 \%$ since the beginning of planting, the highest compared to other treatments, M1a (111.96\%), M1b (109.20), and POO (97.84\%). The highest number of leaf midribs obtained in $\mathrm{M} 0$ a treatment was $17 \%, 51 \%$ and $85 \%$ at three observation periods. The best effect on percentage of growth rate was obtained in treatment M1a of $7.47 \%, 22.40 \%$ and $51.04 \%$ at three observation periods. The highest leaf chlorophyll content was found in $\mathrm{MOa}$ fertilizer treatment, while the highest stomata density was in M1a treatment.

\section{ACKNOWLEDGMENT}

The authors team expressed appreciation and gratitude to the Directorate of Research and Community Service (DRPM) Ministry of Research, Technology and Higher Education at Number: DIPA-042.06.1.401516/2017 with Contract Number: 075.1 / LPPM-Umuslim / KP / 2018 for funding in the Applied Research Scheme in Higher Education.

\section{REFERENCES}

Adam, H., M. Collin, F. Richaud, T. Beule, D. Cros, A. Omore, L. Nodichao, B. Nouy, and J.W. Tregear. (2011). Environmental regulation of sex determination in oil palm: current knowledge and insights from other species. Ann. Bot. 108:1529-1537.

Corley, R.H.V. and P.B.H. Tinker. (2008). The Oil Palm. 4th ed. John Willey and Sons, Oxford, UK.

Ermadani, A. dan Muzar. (2011). Pengaruh aplikasi limbah cair pabrik kelapa sawit terhadap hasil kedelai dan perubahan sifat kimia tanah Ultisol. J. Agron. Indonesia 39:160-167.

Farhana, M.A, Yusop, M.R, Harun, M.H, and Din AK. (2007). Performance of tenera population for the chlorophyll contents and yield component dalam: International palm Oil Congress (Agriculture, Biotechnology and Sustainability). Proceedings of the PPIOC 2007 vol 2; Malaysia: 26-30 Agustus 2007. Malaysia: Malaysia Palm Oil Board. hlm 701-705.

Goh, K.J. and Hardter, R. (2003). General Oil Palm Nutrition.International Potash Institute. p 192 - 230.

Hardjowigeno, S. (2010). IImu Tanah. Jakarta (ID). Akademika Pressindo.

Kanny, P.I., Sudradjat dan Sugiyanta. (2015). The role of manure, nitrogen, phosporus,and potassium fertilizer on growth of two year old palm oil in Jonggol, Bogor,Indonesia. International J of Sciences: Basic and Applied Research (IJSBAR).23(1): 25-33.

Kasno, A., Sudirman, M.T. dan Sutriadi. (2010). Efektifitas beberapa deposit fosfat alam Indonesia sebagai pupuk sumber fosfor terhadap pertumbuhan bibit kelapa sawit pada tanah Ultisol. J. Litri. 16:165-171.

Khatun, R., M. I. H. Reza, M. Moniruzzaman and Z. Yaakob. (2017). Sustainable oil palm industry: The possibilities. Renewable and Sustainable Energy Reviews 76 (2017) 608-619. http://dx.doi. org/10.1016/j.rser.2017.03.077.

Law, C.C., A.R. Zaharah, M.H.A. Husni and A. Siti Nor Akmar. (2012). Evaluation of Nitrogen Uptake Efficiency of Different Oil Palm Genotypes Using ${ }^{15} \mathrm{~N}$ Isotope Labelling Method. Pertanika. J. Trop. Agric. Sci 35 (4): 743-754.

Legros, S., I. Mialet-Sera, J.P. Caliman, F.A. Siregar, A. Clement-Vidal, D. Fabre and M. Dingkuhn. (2009). Phenology, growth and physiological adjustments of oil palm (Elaeis guineensis Jacq) to sink limitation induced by fruit pruning. Ann. Bot. 104:1183-1194. https://doi.org/10.1093/aob/mcp216.

Luz, P.B., A.R. Tavares, P.D. O.P. Paiva, L.A.L. Massoli, F.F.A. Aguiar, S. Kanashiro, G.C. Stancato and P.R.C. Landgraf. (2006). Effects of nitrogen, phosphorus and potassium on early growth of seedlings of Rhapis excelsa (Lady Palm). Ciencia Agrotec. 30:429-434.

Nurseha, Sunarti dan Sri Mulatsih. (2015). Aplikasi Formula Bokashi Kotoran Sapi dan TKSS pada Tanaman Kelapa Sawit (Elaeis guinnensis Jack) Belum Menghasilkan. Jurnal Agroqua Vol.13 No.2, hal 6-14.

Pettigrew, W.T. (2008). Potassium influences on yield and quality production for maize, wheat, soybean, and cotton. Physiol. Plant 131:670-681. 
Poeloengan, Z., M.L. Fadli, Winarna, S. Rahutomo dan E.S. Sutarta. (2001). Permasalahan Pemupukan pada Perkebunan Kelapa Sawit, Lahan dan Pemupukan Kelapa Sawit. Edisi 1. PPKS. Medan

Poeloengan, Z., M.L. Fadli, Winarna, S. Rahutomo dan E.S. Sutarta. (2007). Permasalahan Pemupukan pada Perkebunan Kelapa Sawit. hlm 65-77. Medan (ID): Pusat Penelitian Kelapa Sawit.

Prasetyo, B.H. dan D.A. Suriadikarta. (2006). Karakteristik, potensi, dan teknologi pengelolaan tanah ultisol untuk pengembangan pertanian lahan kering di Indonesia. J Litbang Pertanian.25(2):39-47.

Rachman, I.A., S. Djuniwati dan K. Idris. (2008). Pengaruh bahan organik dan pupuk NPK terhadap serapan hara dan produksi jagung di Inceptisol Ternate. J. Tanah Lingk. 10:7-13.

Rahhutami, R. (2015). Optimasi berbagai taraf pemupukan terhadap pertumbuhan tanaman kelapa sawit belum menghasilkan umur dua tahun [Tesis] Pascasarjana Institut Pertanian Bogor.

Safuan, L.O., Fransiscus, S., Rembon dan H. Syaf. (2013). Evaluasi status hara tanah dan jaringan sebagai dasar rekomendasi pemupukan N, P, dan K pada tanaman kelapa sawit. J Agriplus. 23(2):154-162.

Siallagan, E.J. dan Wardati. (2015). Efektivitas Pupuk Majemuk dan Cu Terhadap Pertumbuhan Vegetatif Tanaman Kelapa Sawit (Elaeis guineensis Jacq.) di Lahan Gambut. Jom Faperta Vol 2 No 1.

Simbolon, D.F. and E. Zuhry. (2017). Pemberian Formulasi Trichokompos TKKS dengan Pupuk NPK pada Pertumbuhan Tanaman Kelapa Sawit (Elaeis guineensis Jacq.) Berasal dari Kecambah Kembar di TBM-I. Jom Faperta Vol. 4 No. 1. Pp. 1-15.

Soon, B.B.F and Hoong, H.W. (2002). Agronomic practices to alleviate soil and surface runoff losses in a palm oil estate. Malaysian J Soil Sci. 6[special ed]:53-64.

Sudradjat, Saputra, H. and S. Yahya. (2015). Optimization of NPK compound fertilizer package rate on one year old oil palm (Elaeis guineensis Jacq.) trees. International J of Sciences: Basic and Applied Research (IJSBAR). 20(1): 365-372.

Suharno, I., Mawardi, Setiabudi, N., Lunga, S. dan Tjitrosemito. (2007). Efisiensi penggunaan nitrogen pada tipe vegetasi yang berbeda di stasiun penelitian Taman Nasional Gunung Halimun Jawa Barat. Biodiversitas. 8:287-294.

Sukmawan, Y, Sudradjat dan Sugiyanta. (2015). Peranan pupuk organik dan NPK majemuk terhadap pertumbuhan kelapa sawit TBM 1 di lahan marginal. J Agron Indonesia. 43(3):242-249.

Sun Xu, C., H.X Cao, H.B Shao, X.T Lei, and Y. Xiao. (2011). Growth and physiological responses to water and nutrient stress in oil palm. African Journal of Biotechnology Vol. 10(51), pp. 10465 10471. DOI: $10.5897 / A J B 11.463$.
Suprayitno, D., Syafrullah, dan N. Amir. (2017). Respon Pertumbuhan Tanaman Kelapa Sawit (Elaeis guineensis Jacq) Terhadap Pemberian Formula Dan Takaran Pupuk Organik Plus Pada Stadia TBM 1. Klorofil. 12(2):100-104.

Syahputra dan Wardati. (2015). Pemberian Pupuk Majemuk NPK dan Cu Untuk Pertumbuhan Tanaman Kelapa Sawit Belum Menghasilkan (Elaeis guineensis Jacq.) di Lahan Gambutjom Faperta Vol. 2 No.1.

Taiz, L., and E. Zeiger. (2006). Plant Physiology. 4th Edition. Sinauer Associates, Inc., Publ. Sunderland, Massachusetts, USA.

Tarmizi, A.M. (2000). Nutritional requirements and efficiency of fertilizer use in Malaysian oil palm cultivation . In: Yusof , B. , Jalani , B.S. , Chan , K.W. (Eds.), Advances in Oil Palm Research , vol. 1 . Malaysian Palm Oil Board, Kuala Lumpur, Malaysia.

Tarmizi, A.M., and Tayeb MD. (2006). Nutrient demands of tenera oil palm planted on inland soil of Malaysia. J Oil Palm Res. 18(6):204-209.

Tiemann, T.T, C.R. Donough, Y.L. Lim, R. Hardter, R. Norton, H.H. Tao, R. Jaramillo, T. Satyanarayana, S. Zingore, and T. Oberth€ur. (2018). Feeding the Palm: A Review of Oil Palm Nutrition. Advances in Agronomy, Volume 152. https://doi.org/10.1016/ bs.agron.2018.07.001.

USDA (2010). Keys to soil taxonomy. United States Department of Agriculture Natural Resources Conservation Service. $11^{\text {th }}$ edition.

Uwumarongie-llori, E.G., B.B. Sulaiman-llobu, O. Ederion, A. Imogie, B.O. Imoisi, N. Garuba, and M. Ugbah. (2012). Vegetative growth performance of oil palm (Elaeis guineensis Jacq.) seedling in response to inorganic and organic fertilizer.Greener J of Agricultural Sciences. 2(2); 1-15.

Wigena, I.G.P., Sudradjat, Sitorus, S.R.P., dan Siregar, H. (2009). Karakterisasi tanah dan iklim serta kesesuaiannya untuk kebun kelapa sawit plasma di Sei Pagar, Kabupaten Kampar, Provinsi Riau. J Tanah dan Iklim. 30(1):1-16.

Woittiez, L.S., M.T. van Wijk, M. Slingerland, M.vanNoorwijk, and K.E. Giller. (2017). Yield gaps in oil palm: A quantitative review of contributing factors. European Journal of Agronomy 83 (2017) 57-77. DOl. http//dx.doi.org/10.1016/j.eja.2016.11.002.

Yahya, S., dan A. Manurung. (2002). Kejut tanam pindah cara cabutan pada pembibitan kelapa sawit. Bul. Agron. 30:12-20.

Zuraidah, Y., Tarmizi, M.A., Haniff, H.M., and Rahim, S.A. (2012). Oil palm adaptation to compacted alluvial soil (typic endoaquepts) in Malaysia. J Oil Palm Res. 24(12):1533-1541. 